\title{
DIGITALCOMMONS
}

5-1-2004

\section{Statistical Pronouncements III}

JMASM Editors

Follow this and additional works at: http://digitalcommons.wayne.edu/jmasm

Part of the Applied Statistics Commons, Social and Behavioral Sciences Commons, and the Statistical Theory Commons

\section{Recommended Citation}

Editors, JMASM (2004) "Statistical Pronouncements III," Journal of Modern Applied Statistical Methods: Vol. 3 : Iss. 1 , Article 28. DOI: $10.22237 /$ jmasm/1083371280

Available at: http://digitalcommons.wayne.edu/jmasm/vol3/iss1/28 


\section{Statistical Pronouncements III}

"It is a curious circumstance that a science so profoundly mathematical as the theory of probability should have originated in the games of chance which occupy the thoughtless and the profligate" - Robert S. Woodward (1906), Probability and theory of errors, NY: Wiley, p. 7.

"Since the beginning of the eighteenth century almost every mathematician of note has been a contributor to or an expositor of the theory of probability" - ibid, p. 8.

"Of all the applications of the doctrine of probability none is of greater utility than the theory of errors" - ibid, p. 9.

"After all, is not faith at the bottom of all scientific knowledge?” - J. V. Uspensky (1937), Introduction to mathematical probability, NY: McGraw-Hill, p. 10.

"The intuition, like the conscience, must be trained" - William Edwards Deming (1950), Some theory of sampling, NY: Wiley, p. viii.

"Statistics are a basis for action" William Edwards Deming, ibid, p. 4.

"The only excuse for taking a survey is to enable a rational decision to be made on some problem” - William Edwards Deming, ibid, p. 545.

"Consult a statistician at an early stage of your planning” - D. H. Finney (1953), An introduction to statistical science in agriculture, Copenhagen: Ejnar Munksgaard, p. 173.

"Do not reject data merely because they seem extraordinary" - D. H. Finney, ibid, p. 174.

"When you are experienced enough to make your own statistical analyses, be sure you choose the right technique and not merely any one that you can remember!” - D. H. Finney, ibid.
"To put too many entries into one table or too many curves on one diagram ensures that few will read and fewer understand it” - D. H. Finney, ibid.

"Express your conclusions in terms of the subject under investigation and its behaviour, with a minimum of statistical jargon" - D. H. Finney, ibid.

"Remember that no amount of statistical manipulation can make a bad experiment give good results” - D. H. Finney, ibid.

"In order to optimize my expenditure of effort, I divide intellectual difficulties into two classes: those which worry me and those which do not” - Maurice G. Kendall, (1961) Presidential Address, Journal of the Royal Statistical Society, 124(A), p. 11.

"Not only can choice mimic chance, but chance can mimic choice” - Maurice G. Kendall, ibid, p. 12.

"The typical inference of the detective, historian, or conjecturing mathematician and the clever inferences of science are not statistical inferences” - Leonard J. Savage (1962), The foundations of statistical inference, London: Methuen, p. 11.

"I have a natural sympathy with anyone who is trying to thrash out better ways of handling the problems of statistical inference" Egon Sharpe Pearson, ibid, p. 53.

"Through the lack of close contact with my partner during the last twenty years, it would be a little difficult to say where precisely the Neyman and Pearson theory stands today" Egon Sharpe Pearson, ibid.

"Significance tests, in their usual form, are not compatible with a Bayesian attitude" C. A. B. Smith, ibid, p. 60. 
"What I, and many other statisticians, call the Neyman-Pearson view may, for all I know, never have been held by Professor Neyman or by Professor Pearson" - Leonard J. Savage, ibid, p. 62.

"Probability theory as such presents ideological difficulties for communism” - R. Syski, ibid, p. 86.

"The objectives of randomization: to make the experiment useful to others and to guard against one's own subconscious" Leonard J. Savage, ibid, p. 88.

"Such rumours as that artists can make more random-looking designs than random number generators can are a little disquieting" Leonard J. Savage, ibid, p. 89.

"Ignoring Baye's Theorem has put much of modern statistics out of gear with scientific thinking”- G. M. Jenkins, ibid, p. 94.

"I regard the separation between statistician and client as an accidental detail of real life that we should try to overcome”, Leonard J. Savage, ibid, p. 99.

"Cambridge University”, said Fisher, "should never appoint a professor who is older than 39. If they do, then by the time his proposal for his teaching program has been approved by the university, he will have reached retirement age” - attributed to Ronald A. Fisher by William G. Cochran (1967), Footnote, Science, 156(3781), p. 1460.

"I have often wondered, as I suppose does Neyman, why Fisher seems not to have regarded the power of the test as relevant, although he developed the power functions of most of the common tests of significance" William G. Cochran, ibid, p. 1461.

“The $l$-statistics are called 'polykays' by some authors, but we feel that there are limits to linguistic miscegenation which should not be exceeded" - Maurice G. Kendall, (1969), The advanced theory of statistics, ( $3^{\text {rd }}$ ed.), London: Charles Griffin \& Co., p. 303.
"They have not converted me to thinking factor analysis is worth the time necessary to understand it and carry it out" - $\mathrm{M}$. Hills (1977), Book review, Applied Statistics, 26, p. 339-340.

"Mathematics... is purely an abstract enterprise that need have nothing to do with the real world... Thus the statement iggle wug drang flous could be a legitimate mathematical statement in a set of rules stating that when any iggle is wugged it drang a flous... Of course... [this] might not be of any practical use" - Jum C. Nunnally (1978), Psychometric theory, ( $2^{\text {nd }}$ ed.). NY: McGraw-Hill, p. 9-10.

"A random sample is random because of the sampling procedure used to select it, not because of the composition of the sample" Eugene S. Edgington, (1980), Randomization tests, NY: Dekker, p. 2.

"Ninety per cent all the mathematics we know has been discovered (or invented) in the last hundred years" - George Temple (1981), 100 Years of mathematics: A personal viewpoint. NY: Springer-Verlag, p. Xv.

"The great advances in mathematics have not been made by logic but by creative imagination" - George Temple, ibid, p. 3.

"Why does the appalling ignorance of statistics persist in spite of the great number of books written on the subject? Simple - the books are written in a foreign language" - Myles Hollander \& Frank Proschan (1984), The statistical exorcist: Dispelling statistics anxiety. NY: Dekker, p. v.

"The rotation of factors is not intrinsically subjective in nature" - Alexander Basilevsky (1994), Statistical factor analysis and related methods, NY: Wiley, p. xii.

"Does the Monte Carlo method help one win at roulette? The answer is No" - Ilya A. Sobol (1994), A primer for the Monte Carlo method. Boca Raton, FL: CRC Press, p. vi. 